Chirurgia (2018) 113: $644-650$

No. 5, September - October

Copyright@ Celsius

http://dx.doi.org/10.21614/chirurgia.113.5.644

\title{
Skin Grafting in the Treatment of Diabetic Foot Soft Tissue Defects
}

\author{
Anca Bordianu', Florin Bobircă², Traian Pătrașcu² \\ "'Bagdasar-Arseni" Emergency Hospital, Plastic and Reconstructive Department, Bucharest, Romania \\ 2"Dr I. Cantacuzino" Clinical Hospital, General Surgery Department, Bucharest, Romania
}

Corresponding author:

Florin Bobircă, MD

"Dr I Cantacuzino" Clinical Hospital

General Surgery Department

5-7 Ion Movila Street, Bucharest

Romania

E-mail: dr.bobirca@gmail.com
Received: 09.07.2018

Accepted: 11.09 .2018

\section{Rezumat}

Plastia cu piele liberă în tratamentul defectelor de părți moi ale piciorului diabetic

Introducere: Potrivit Organizației Mondiale a Sănătății, cazurile de diabet zaharat au crescut de la 108.000.000 în 1980 la 422.000.000 în 2014, cu o creştere mai rapidă în țările cu venituri mici şi mijlocii. Diabetul cauzează anual aproximativ 1.600 .000 decese şi este o cauza majoră de infarct miocardic, accident vascular cerebral, insuficiență renală, orbire şi amputarea membrelor inferioare. Acest articol oferă informații cu privire la tratamentul unei complicații frecvente legate de diabet zaharat, şi anume amputatia piciorului. Defectele mari si profunde ale piciorului diabetic reprezintă o provocare reconstructivă. Scopul studiului este de a analiza eficiența metodelor de vindecare folosind grefă de piele coroborat cu terapia cu presiune negativă pentru plăgile rezultate după o intervenție chirurgicală a piciorului diabetic. În al doilea rând, studiul intenționează să sublinieze rolul unei secvențe a abordării multidisciplinare, în acest caz chirurg generalistchirurg plastician, în asigurarea funcționalității membrelor pelvine.

Material şi Metodă: Au fost analizati retrospectiv 63 de pacienți cu diabet zaharat, pacienți care au fost internați în spitalele clinice Dr. I. Cantacuzino şi Bagdasar-Arseni, cu diferite tipuri de plagi rezultate după intervențiile chirurgicale ale piciorului diabetic, între ianuarie 2016 şi decembrie 2017.

Rezultate: Reconstrucțile au avut succes pentru 56 de pacienți, iar în timpul perioadei de urmărire nu au existat complicații. Din cei 7 pacienți cu complicații (necroză de grefă cutanată, infecție a grefei), 
unul a prezentat o auto-avulsie a grefei cutanate.

Concluzii: Inchiderea directă este posibilă pentru plagile de dimensiuni mici. Grafturile de piele oferă o acoperire eficientă pentru plăgile mari, deşi pot produce adesea închideri concave, escavate, neestice. NPWT (terapia cu presiune negativa) este, de asemenea, o procedură foarte utilă. Reconstrucția cu lambouri oferă adesea un aspect funcțional şi estetic superior. Transferurile libere pot fi utilizate pentru a închide multe plagi, însă restrictia dermica poate împiedica mişcarea şi poate duce la aparitia tensiunii. Soluția alternativă rămâne reconstrucția cu lambouri libere, care poate prezenta si ea probleme, din cauza arteriopatiei.

Cuvinte-cheie: diabet, picior diabetic, grefă de piele, terapie cu presiune negativa, amputație a piciorului

\begin{abstract}
Background: According to the World Health Organization, cases of diabetes have risen from 108 million in 1980 to 422 million in 2014, with a more rapid rising in middle- and low-income countries. Diabetes causes yearly approximately 1.6 million deaths, and is a major cause of heart attacks, stroke, kidney failure, blindness and lower limb amputation. This article provides information on the treatment of a frequent complication related to diabetes, namely toe/ partial foot amputation. Broad, deep operative defects of the diabetic foot represent a reconstructive challenge.

The aim of the study is to analyse the efficiency of healing methods using splitted skin graft corroborated with negative pressure therapy for wounds resulted after diabetic foot surgery. Second of all, the study intends to highlight the role of a sequence of the multidisciplinary approach, in this case general surgeon-plastic surgeon, in assuring the functionality of the pelvic limb.

Methods: 63 diabetic patients were retrospectively analysed, patients that were admitted in Dr.I.Cantacuzino and Bagdasar-Arseni Clinical Hospitals, with different types of wounds resulted after diabetic foot surgery, between January 2016 and December 2017.

Results: The reconstructions were successful in 56 patients, and, during the follow-up period, there were no complications. From the 7 patients with complications (skin graft necrosis, skin graft infection), one had an auto avulsion of the skin graft.

Conclusion: Direct closure is feasible for small-sized wounds. Skin grafts provide effective coverage for large wounds, although they may often produce concave, caved-in, non-aesthetic closures. NPWT (negative pressure wound therapy) is also a very helpful procedure. Flap reconstruction often provides superior functional and aesthetic appearance. Adjacent tissue transfers may be used to close many wounds, but dermal restraint may hinder motion and lead to closure tension. Alternative solution of repair remains the reconstruction with free flaps, which also poses problems, due to arteriopathy.
\end{abstract}

Key words: diabetes, diabetic foot, splitted skin graft, negative pressure wound therapy, foot amputation

\section{Introduction}

Diabetes is an increasingly frequent disease, which leads to several major complications, and represents, worldwide, an important cause of death. Age, smoking, ethnicity, family history, obesity, and physical inactivity are factors that may increase risk in patients. The diabetic foot is among the most common macrovascular complications related to diabetes, with an average of $15 \%$ of diabetic patients having to face non-traumatic lower 
extremity amputations $(1,2,3)$.

Diabetic foot wounds are very complex, tend to rapidly become chronic wounds, and the treatment is usually very difficult, especially for those secondary to amputation $(3,4,5)$. The goal in any reconstructive method is to effect tension-free closure, providing optimal function, and an aesthetic outcome.

Soft tissue defects of the diabetic foot might result from peripheral arterial disease, soft tissue infection (non-traumatic causes), trauma and burns. Also, the risk factors include foot deformities, peripheral neuropathy, abnormal foot pressure, limited joint mobility, and, last but not least, a history of amputation and/or ulceration. Several studies reported that around $85 \%$ of all diabetic foot amputations are preceded by foot ulcers $(4,5,6,7)$.

Direct closure is effective for small to medium sized wounds. Very broad, shallow wounds are often best managed with skin grafts. Medium-sized wounds are often reparable with local adjacent tissue transfers. Broad, deep wounds pose the greatest reconstructive challenge. For large, extensive defects, free flaps may be used, but isolating suitable recipient vessels may be problematic, and the donor site morbidity is substantial, due to peripheral arterial disease $(8,9,10,11)$.

NPWT (negative pressure wound therapy), used in diabetic patients after toe or partial foot amputation, or even after infections, showed improved wound healing with a faster rate of granulation tissue formation in the wound bed. NPWT is safe, effective and reliable in treating complex diabetic foot wounds, and could lead to faster healing $(9,12,13)$.

Depending on the defect level, a freestyle propeller flap can be used (rotated and transposed as an island flap based on a single, reliable perforasome). The design of the propeller flap allows for a relatively tensionfree closure of the operative wound and, with primary closure, a minimal morbidity of the donor site.

The propeller flap concept requires careful patient selection, meticulous preoperative planning, accurate vessel identification, proper dissection technique, and precise suturing.
With appropriate planning and execution, the propeller flap has a low morbidity and high success rate. However, in diabetic patients, especially senior patients with complications of the diabetic disease, success rate of flaps is very low, due to presence of peripheral arterial disease $(14,15)$

The aim of the article is to analyse the efficiency of the reconstructive methods of the diabetic foot defects using conventional skin graft, corroborated with NPWT. The patients come from a center in which are treated yearly 800-1000 patients with diabetic foot pathology.

\section{Materials and Methods}

The study reviews and analyzes the efficiency of splitted skin graft used for treating different wounds of diabetic foot in 63 patients, 41 men and 22 women, between January 2016 and December 2017. There were several inclusion criteria: only diabetic patients, granulated and bacteria free wounds, compliant patients to follow the postoperative recomandations.

The patients' age ranged between 55 and 93 years old, with an average age of 68 years. 47 patients were smokers, and 16 were nonsmokers. 33 of patients were predominant with vascular diabetic disease, 30 were with predominant neuropathic diabetic disease. All of the wounds resulted from surgical treatment: amputation of toe(s)/foot for gangrene or osteoarthritis (Fig. 1). 4 cases were with diabetic Charcot foot.

Negative pressure wound therapy (NPWT) was used in 36 patients to obtain a granulated wound prior to reconstructive surgery (Fig. 2) This method played an important role in the treatment of complex ulcerations of diabetic foot.

The efficacy of NPWT on limb salvage of the diabetic foot is well described in the literature. Nevertheless, the use of this method requires a multidisciplinary approach, and a good surgical debridement.

From 63 patients with transmetatarsal amputations of toe/foot, 36 patients received NPWT, followed by coverage with a split- 
Figure 1. Initial aspect
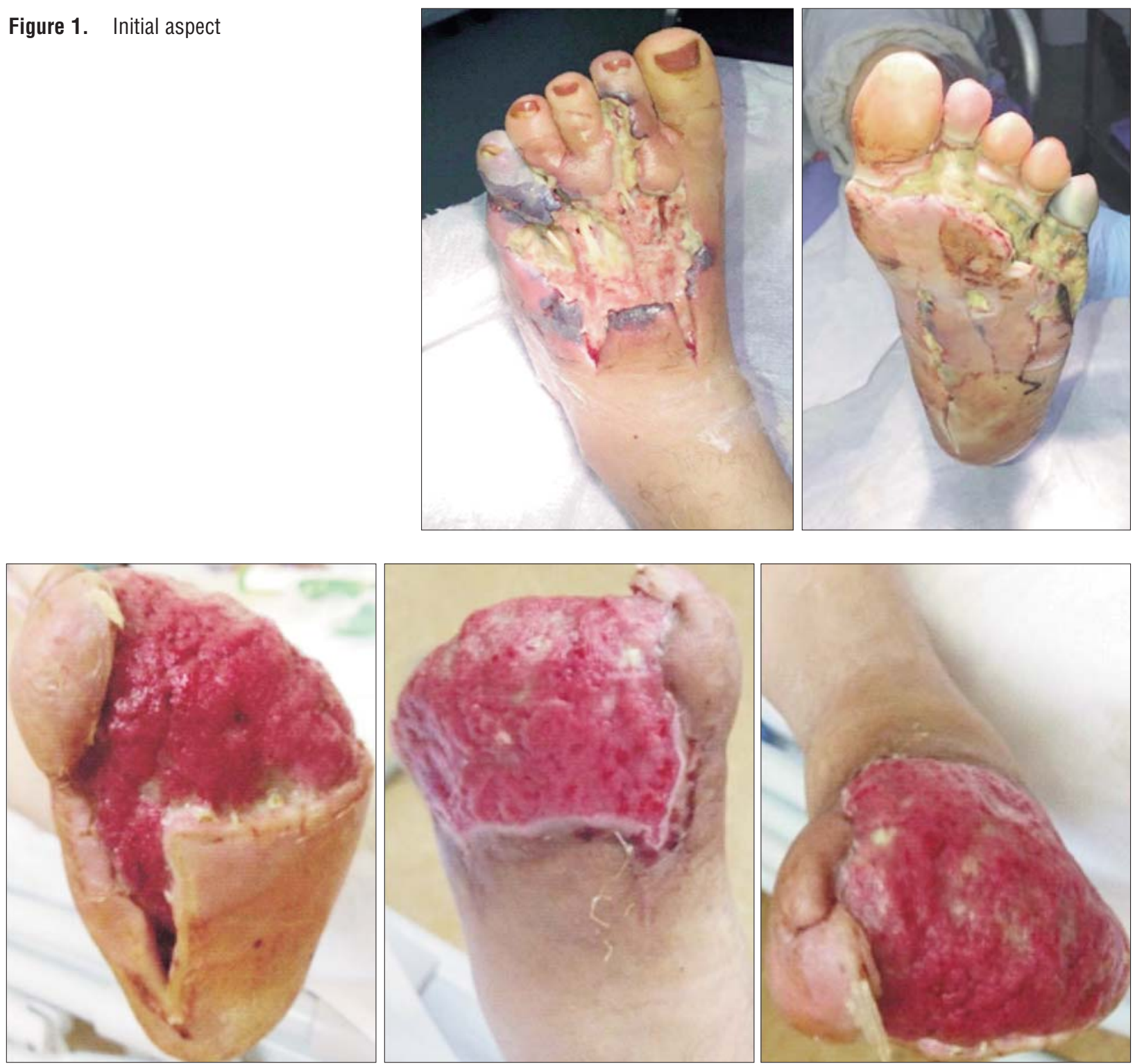

Figure 2. Preoperative wound after using NPWT

thickness skin graft (STSG) (Fig. 3); for the rest of the patients $(n=17)$, who presented good quality granulation tissue, we used only STSG.

\section{Results}

This study reviews 63 cases of diabetic foot wound reconstructions, and evaluates the outcome of the used methods.

The reconstructions were successful in 56 patients, and, during the follow-up period, there were no complications. The results of these reconstructive options were satisfactory in terms of functionality and aesthetic outcome (Figs. 3, 4)

For 7 patients there were several complication: 3 cases of skin graft necrosis due to the lack of blood supply, 2 cases of partial skin necrosis, that needed a longer time for healing, 2 cases of skin graft infection, that made necessary the treatment with antibiotics and 1 case was with auto avulsion of the skin graft. All of the other reconstructions with STSG were successful and 
Figure 3A. STSG.

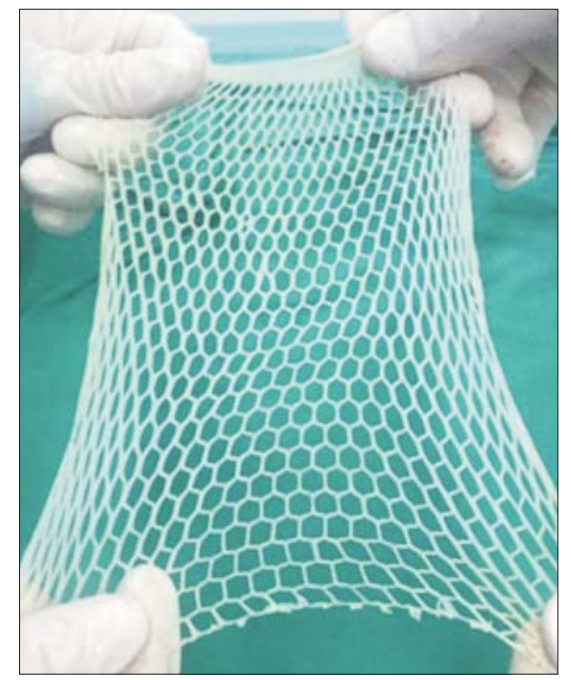

with a good outcome (Table 1).

The donor site was in all of the 63 patients located at the thigh, in 6 cases the patients developed donor site infection, that needed treatment with antibiotics, with good outcome, there was no need for surgery.

The length of hospital stay ranged between 5 and 14 days, with an average of 7 days. The period until complete healling of the skin graft was between 4 weeks and 3 months, due to the poor vascular supply of diabetic patients.

\section{Discussion}

Large, deep and complex wounds of the diabetic foot represent a challenge to the reconstructive surgeon.

There were 4 cases of skin graft necrosis, this is due to the poor vascularisation. The blood supply is very important in order to consider the indication for skin grafting. For the predominat arteriopathic diabetic patients, in most cases, is was needed to perform a vascular desobstruction method before covering the defect, to ensure the healing process.

For the predominant neuropathic patient

Table 1. Results after split thickness skin graft procedure

\begin{tabular}{lcccc}
\hline Good outcome & \multicolumn{4}{c}{ Complications STSG } \\
\hline & necrosis & partial necrosi & infection & avulsion \\
\hline 56 & 3 & 2 & 2 & 1 \\
\hline
\end{tabular}
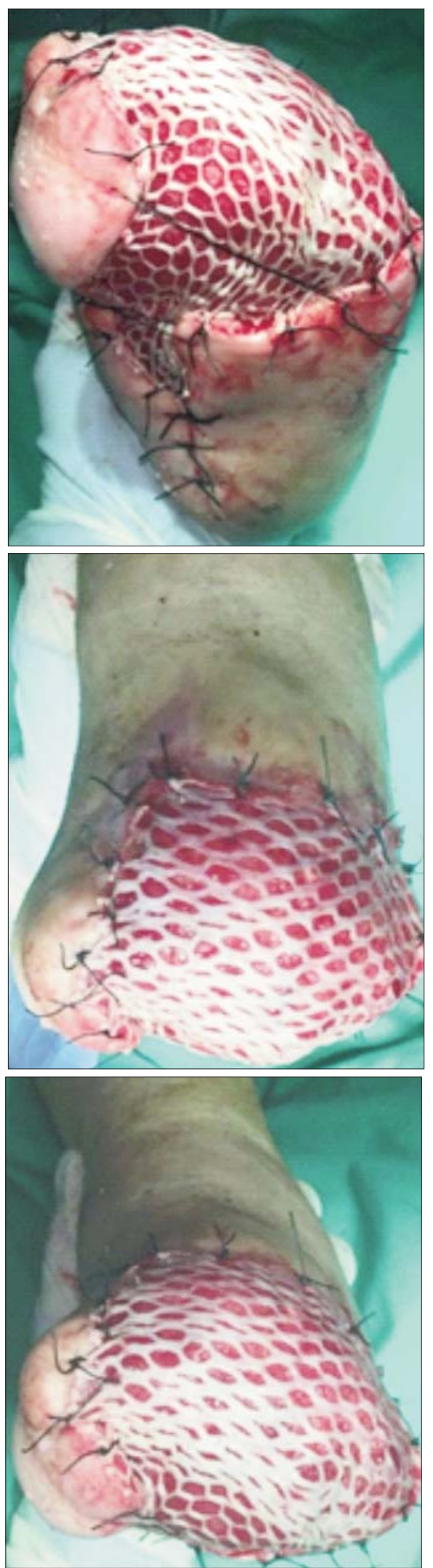

Figure 3B. Skin grafted wound - immediate postoperative appearance 


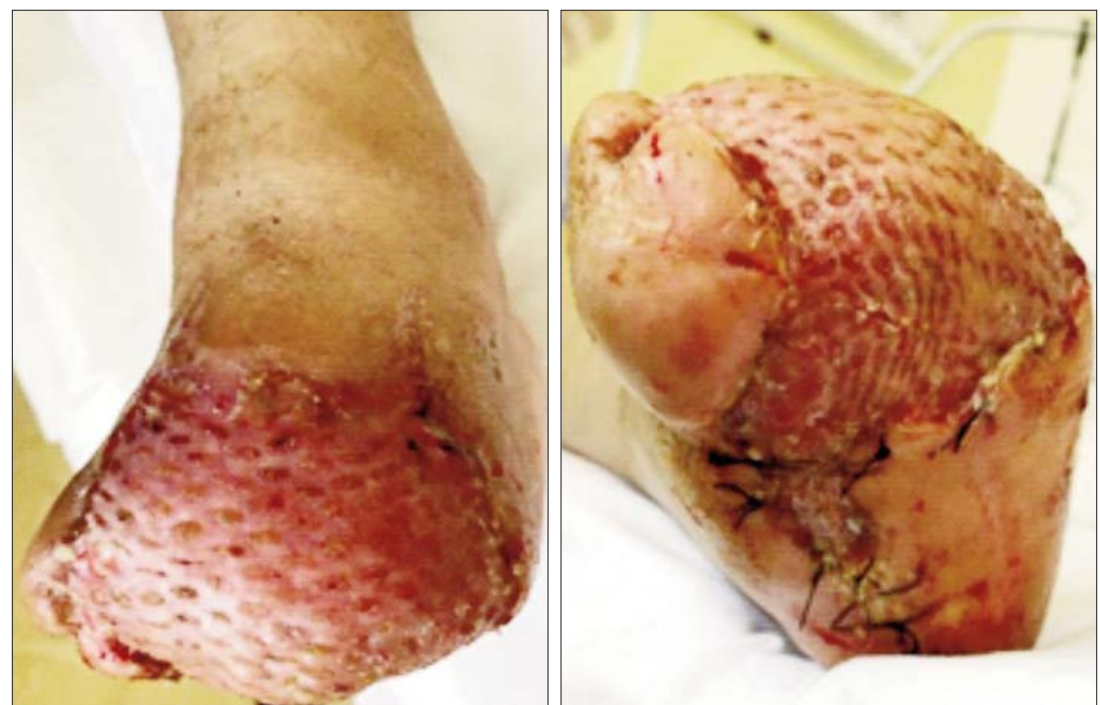

Figure 4. Skin grafted wound - postoperative appearance after 10 days

the evolution of the skin graft is often good if the healing process does not show any bacterial contamination. For the patients that developed donor site infection there was no need for surgery, only wound dressing and antibiotics were used.

The hospital stay was smaller then a normal duration for a patient with diabetic foot pathology.

Patient collaboration is very important in ensuring the healing process, meaning that recommendations on special dressing, footwear and effort must be strictly followed.

A multidisciplinary approach is needed to ensure healling (eg general surgeons, plastic surgeons, vascular surgeons, nurses). Diabetic foot ulcers have a high risk of amputation and thus an increased rate of mortality $(16,17)$.

A good management of diabetes and a periodical screening of those patients can prevent of at least delay foot ulcers. The main factors of diabetic foot ulcers are peripheral arterial disease, deformity, infection and also previous amputations $(6,18,19)$.

\section{Conclusions}

Skin grafting is feasible in diabetic patients with chronic wounds even in the case of the predominat arteriopathic one, if revascu- larization is previously done.

Total or partial necrosis of the skin graft can occur and its corelatted to prolonged healing period and an increased need for hospitalisation.

The goals of skin grafting for diabetic foot wound are: to assure the functionality of the diabetic foot and to decrease the overall morbidity.

Diabetic foot wounds are very complex, rapidly becoming chronic wounds. The treatment is usually very difficult, and, in the majority of cases, amputation is the final solution.

The indication for skin grafting is much easier to establish for predominantly neuropathic patients, for the patients with vascular diabetic disease it is necessary to consult a vascular surgeon before reconstructive methods are applied.

NPWT (negative pressure wound therapy) helps in improving wound healing, due to faster rate of granulation. NPWT is safe, effective and reliable in treating complex diabetic foot wounds, and could lead to faster healing.

While using a flap could be a surgical option for wound closure, due to increased risks of failure, caused by peripheral arterial disease, and other associated comorbidities, it is a less used surgical solution.

Coverage with a split-thickness skin graft 
(STSG), associated with prior NPWT, is a safe, easy, reliable and cost effective solution in the management of diabetic foot wounds.

\section{Conflict of Interests}

The authors declare that they have no conflict of interests.

\section{Funding}

The authors received no financial support for the research, authorship, and/or publication of this article.

\section{References}

1. World Health Organization, http://www.who.int

2. Deshpande AD, Harris-Hayes M, Schootman M. Epidemiology of diabetes and diabetes-related complications. Phys Ther. 2008; 88(11):1254-64.

3. Jeffcoate WJ, Harding KG. Diabetic foot ulcers. Lancet. 2003; 361(9368):1545-51.

4. Alexiadou K1, Doupis J. Management of diabetic foot ulcers Diabetes Ther. 2012;3(1):4.

5. Jang MY, Hong JP, Bordianu A, Suh HS. Using a contradictory approach to treat a wound induced by hematoma in a patient with antiphospholipid antibody syndrome using negative pressure wound therapy. Int J Low Extrem Wounds. 2015;14(3):303-6.

6. Alavi A, Sibbald RG, Mayer D, Goodman L, Botros M, Armstrong DG, et al. Diabetic foot ulcers: Part I. Pathophysiology and prevention. J Am Acad Dermatol. 2014;70(1):1.e1-18; quiz 19-20.
7. Kim EK, Hong JP. Efficacy of negative pressure therapy to enhance take of 1-stage allodermis and a split-thickness graft. Ann Plast Surg. 2007;58(5):536-40.

8. Lee KN, Ben-Nakhi M, Park EJ, Hong JP. Cyclic negative pressure wound therapy: An alternative mode to intermittent system. Int Wound J. 2015;12(6):686-92.

9. CADTH Rapid Response Reports. Debridement procedures for managing diabetic foot ulcers: a review of clinical effectiveness, cost-effectiveness, and guidelines. Ottawa (ON): Canadian Agency for Drugs and Technologies in Health; 2014 Sep. [Internet].

10. Bobircă F, Mihalache 0 , Georgescu D, Pătrascu T. The new prognostic - therapeutic index for diabetic foot surgery - extended analysis. Chirurgia (Bucur). 2016;111(2):151-5.

11. Bobircă $F$, Catrina E, Mihalache 0 , Carniciu S, Pătrascu T. The therapeutic attitude in treating lesions of the arteriopathic predominant diabetic foot. J. Transl. Med. Res. 2014;19(1-2): 41-46.

12. Suh HS, Hong JP. Diabetic foot ulcer. J Korean Med Assoc. 2015; 58(9):795-800. Korean

13. Hong JP, Oh TS. An algorithm for limb salvage for diabetic foot ulcers. Clin Plast Surg. 2012:39(3):341-52.

14. Tang ZQ, Chen HL, Zhao FF. Gender differences of lower extremity amputation risk in patients with diabetic foot: a meta-analysis. Int J Low Extrem Wounds. 2014;13(3):197-204.

15. Jolly GP, Zgonis T, Blume P. Soft tissue reconstruction of the diabetic foot. Clin Podiatr Med Surg. 2003;20(4):757-81.

16. Sanniec K, Nguyen T, van Asten S, Fontaine J, Lavery LA. SplitThickness Skin Grafts to the Foot and Ankle of Diabetic Patients. J Am Podiatr Med Assoc. 2017;107(5):365-368.

17. Iliescu V, Jiga LP, Ionac M. Complex microsurgical reconstruction of diabetic foot. Chirurgia (Bucur). 2005;100(2):181-6. Romanian

18. Anderson JJ, Wallin KJ, Spencer L. Split thickness skin grafts for the treatment of non-healing foot and leg ulcers in patients with diabetes: a retrospective review, Diabet Foot Ankle. 2012;3. doi: 10.3402/dfa.v3i0.10204. Epub 2012 Feb 20.

19. Wang J, Gao L, New progress in the treatment of chronic wounds of diabetic foot. Zhongguo Xiu Fu Chong Jian Wai Ke Za Zhi. 2018; 32(7):832-837. Chinese 